\title{
Razones de las reformas ortográficas en la América independiente y causas de su fracaso
}

\author{
Juan Antonio Frago* \\ Universidad de Zaragoza, España
}

\begin{abstract}
Resumen
El reformismo ortográfico americano fue aspecto importante de la tendencia a la normatividad lingüística que ocupó el discurso y los afanes educativos de las elites cultas. En la ortografía se visualizaba la corrección o incorrección idiomática del individuo, así como los principales rasgos de la fonética criolla, y la tajante condena que se sigue contra las faltas que en su empleo se cometían va envuelta de propósitos de redención social y de apoyo al progreso nacional. La reorganización y simplificación del corpus alfabético busca allanar la enseñanza de la escritura con regularidad ortográfica, y bajo la guía del principio de la pronunciación algunos cambios se justifican por la que se siente como propia, en Sarmiento a veces con argumentos para afirmar la ortografía como nexo identificativo de la americanidad. Pero las reformas nacieron acompañadas de la polémica y de no pocas resistencias, la más decisiva de las cuales a la postre sería la extrema dificultad, insuperable como se vio, de que en el conjunto de la América del siglo XIX triunfara cualquier propuesta, incluso la de más prudente alcance, de separarse de un acervo y de unos usos ortográficos que en realidad no eran solo de la Academia española, sino comunes a todo el mundo hispánico.
\end{abstract}

Para correspondencia dirigirse a: Juan Antonio Frago Gracia (jafrago@unizar.es), Departamento de Lingüística General e Hispánica, Facultad de Filosofía y Letras, Universidad de Zaragoza, Pedro Cerbuna 12, 50009 Zaragoza, España. 
Palabras clave: norma ortográfica y norma lingüística, principios del reformismo americano, causas de su fracaso.

\title{
REASONS FOR ORTHOGRAPHIC REFORMS IN INDEPENDENT AMERICA AND CAUSES OF THEIR FAILURE
}

\begin{abstract}
The American orthographic reforming attitude was an important aspect of the tendency towards linguistic, a central topic of the educational concern and discourse of the intellectual elites. Orthography was considered as the reflection of an individual's idiomatic correctness or incorrectness, where the principal traits of Hispanic American phonetics could be observed, and the definite condemnation of the non-observance of its rules is motivated by social redemption and national progress support. The reorganization and simplification of the alphabetic corpus aims at smoothing the teaching of writing with orthographic regularity, and under the ruling of the pronunciation principle some changes are justified by that form that is felt characteristic, in Sarmiento sometimes with arguments to strengthen orthography as an identifying link with Americanity. But reforms were born together with discussion and opposition, the most decisive of which was the extreme difficulty to bring about even the simplest of modifications in the whole of Hispanic America in the XIX century. It was impossible to get away from a patrimony and orthographical usages that not only belonged to the Spanish Academy but that were common to the Hispanic world.
\end{abstract}

Key words: orthographic norms and linguistic norms, principles of American reforming attitude, causes of their failure.

Recibido: 30/08/2012 Aceptado: 28/11/2012 


\title{
1. DE LA IDEOLOGÍA PATRIÓTICA A LA NORMATIVIDAD LINGÜÍSTICA ${ }^{1}$
}

\begin{abstract}
1.1. Entre los retos que a los pueblos americanos la libertad recién alcanzada planteaba el de la búsqueda de la identidad nacional ocupaba lugar central en sus urgencias ideológicas y organizativas, necesidad sociopolítica esencial que, naturalmente, ya se sintió en los convulsos trances de la guerra emancipadora, sin que la construcción de independencias regionales sobre la anterior geografía virreinal se viera reñida con el hermanamiento de la americanidad, a veces en términos un tanto difusos. Es un hecho que en las nuevas repúblicas se hicieron recurrentes los términos lengua patria e idioma nacional, que, por ejemplo, figuran en páginas periodísticas santiaguinas de 1828 (Cid 2009: 66, 92) ${ }^{2}$. Y en el primero de los artículos citados su autor, al combatir la indiscriminada aceptación de "los galicismos más desatinados" y defender "el esmero de la locución y la severidad de la oratoria", concluía:
\end{abstract}

Si los preceptores de nuestra juventud la adoctrinasen antes de todo en el arte esencialísimo de hablar, que es la verdadera lógica y que forma para toda la vida el molde del raciocinio, en fin, si considerásemos que el idioma como parte integrante de la nacionalidad, del mismo modo que lo son las leyes que nos rigen y el territorio que habitamos, la opinión pública se manifestaría inexorable contra los que la adulteran y la falsifican (94).

Pero tan lengua patria o nacional consideraban al español hablado en Chile quienes no abominaban del préstamo francés, o al menos no con tanta rigidez purista. Natural es, sin embargo, que el impulso emancipador llevara aparejada una "feliz revolución de las ideas", en palabras del redactor del primero de estos opúsculos (64), y que algunas rayaran en la utopía o en la pura idealización patriótica. Como cuando en el segundo texto periodístico se afirma que uno de los obstáculos opuestos "a los adelantos de la elocuencia"

\footnotetext{
1 Del proyecto de investigación FFI2011-24806, Ministerio de Economía y Competitividad.

2 La primera expresión, en el artículo "Educación. Observaciones sobre la enseñanza científica y sobre el régimen de los colegios" (pp. 63-70), publicado el 1 de abril de 1828 en el núm. 1 de El Mercurio Chileno; la segunda, en el titulado "Literatura. De la elocuencia parlamentaria" (pp. 92-98), del 1 de mayo, núm. 2 de este periódico. Las citas de estos textos en adelante se harán solo por las páginas en que aparecen, lo mismo que las que reiteradamente sean necesarias de otras referencias bibliográficas, cuando no haya equívoco en su identificación.
} 
en América sería "la viveza del carácter nacional, que muchos atribuyen a la suavidad del clima y a la ligereza de la atmósfera", y que esto por un lado "favorece la facilidad de la penetración y suministra al lenguaje expresiones enérgicas, figuras osadas y argumentos vehementes", mientras impide "escuchar con serenidad, pesar las objeciones contrarias y meditar de sangre fría las respuestas" (94-95). Ahora bien, estos números inaugurales de El Mercurio Chileno también se hacen eco de principios ideológicos y criterios sociales fundamentados en el convencimiento democrático y liberal de que el sistema de promoción social del antiguo régimen debía sustituirse por el mérito del individuo, pues la revolución "ha dado a la razón todos sus derechos", necesariamente impartidos por "una nueva autoridad, que juzga irrevocablemente toda especie de mérito", autoridad identificada con "lo que se llama opinión o razón pública", y siendo que "la utilidad es la única regla de sus decisiones", obligado era que "todos los estudios que demos a la juventud, en la época presente, deben tener por objeto la utilidad" (64).

El utilitarismo con que la ciencia y su enseñanza se encaran para el logro del progreso nacional y también con fines patrióticos, la efectiva ampliación de la ciudadanía a los iletrados mediante el ejercicio del derecho al voto, que requería su alfabetización, tendrá como consecuencia el cultivo del idioma como herramienta fundamental del sistema educativo, porque "el lenguaje... es el órgano más digno que puede escoger la razón para consignar sus progresos", y porque "pensar con exactitud y hablar con claridad y elegancia son condiciones tan necesarias al abogado como al militar, al legislador como al economista" $(65)^{3}$. El autor del segundo artículo igualmente sostiene que "pensar bien y hablar correctamente son operaciones sumamente análogas, porque el habla no es más que el pensamiento comunicado, y es difícil que no tengan un gran influjo recíproco cosas que están continuamente en tan íntimo contacto" (93). Este ideario, en el que un cuidado uso de la lengua se entiende necesario para la lógica del raciocionio, entronca con las doctrinas educativas y gramaticales francesas que influyeron en los ilustrados españoles interesados por la cuestión pedagógica, y que en la América independiente tuvieron campo abonado para su aplicación. No extraña, así, que Andrés Bello comenzara su ensayo ortográfico de 1823 recordando de esta manera

\footnotetext{
3 En cuanto a la elección del método y de los tiempos educativos, este autor, en línea con un pensamiento muy extendido en los Siglos de Oro, opina que "la (gramática) de la lengua patria pasa generalmente por un estudio indispensable en la niñez, y nosotros lo creemos enteramente inútil en aquella época de la vida", y defiende que "conviene saber la gramática del idioma en que pensamos, mas un estudio tan penoso y complicado forma parte del arte de pensar, y solo debe emprenderse cuando se puede pensar por sí mismo" (66).
} 
a Rousseau: "Se forman las cabezas por las lenguas, dice el autor del Emilio, y los pensamientos se tiñen del color de los idiomas" (ASALE 2010a: 15).

1.2. Consecuencia de este poso filosófico y de ideología política fue que en la elite cultural americana se impusiera la opinión de que "en un siglo que se distingue por la perfección de todos los ramos que contribuyen al esplendor de las sociedades, no son de pequeña importancia el esmero de la locución y la severidad de la oratoria" (94), y en este deseo de selección idiomática queda explícitamente marcada la dicotomía en los modelos sociolingüísticos que marcan las palabras del articulista, con subrayado mío: "el idioma es el barómetro de los progresos intelectuales; puro, noble, acendrado, o tosco, envilecido y descompuesto, según suben o bajan el cultivo de la razón, el amor a las luces y la independencia del espíritu" (93). Sería la preeminencia del lenguaje de los "eruditos" frente al "defectuoso" de aquellos "que no se han aplicado a hablar con perfección", según el anónimo Catálogo de 1843 (Ferreccio Podestá 1979: 44); y Bello en sus Advertencias sobre el uso de la lengua castellana distinguiría, en términos de estricta prescripción normativa, entre "los que se cuidan de evitar todo resabio de vulgarismo" y los que practican "el barbarismo grosero" (ASALE 2010a: 45, 59). No era radicalmente nueva esta dicotomía sociolingüística, con antecedentes de siglos, frecuentemente tópicos, en la cultura española, desde el humanismo renacentista que contrapone el habla de la corte (la ciudad) a la de la aldea, y con próximo testimonio mexicano, en el que el Padre (clérigo, hablante culto), se refiere al modo de expresarse el indio Juan Diego con el mismo adjetivo (grosero) que emplea Bello en la anterior cita: "Señor, se fue / yo le despedí temiendo / molestase a su Yllustrísima / por lo rústico y grocero de sus voces" $"$.

1.3. Las revoluciones independentistas recogen y mejoran el testigo virreinal de una extrema contraposición del habla culta al modelo más crudamente vulgar, a grandes trazos caracterizado anteriormente por unos pocos rasgos lingüísticos tradicionalmente ajenos al uso de las gentes cultivadas, pero en diversa medida asimismo connotado de coloquialismos y, sobre todo, convencionalmente alterado fonética y gramaticalmente cuando el

$4 \quad$ En el Coloquio de Nuestra Señora de Guadalupe, de José Protasio Beltrán (c. 1807). Biblioteca Nacional de España, Ms. 3167, 47v. 
representante de la clase baja era un personaje negro o indio, porque literario generalmente fue el recurso a este tópico cuadro sociolingüístico. La entrada del siglo XIX conoce casos textuales de notable depuración de un argumento tanto tiempo manejado con fines humorísticos, en los que la referencia idiomática se presenta con marcados ribetes de realidad social y dialectal, como aquel coloquio mexicano de c. 1807, en el que sistemáticamente se oponen varios registros del hablante inculto a sus correspondencias cultas, entre ellos el rural -ites, segunda persona singular del pretérito simple (dixites), al urbano-iste (volviste) $)^{5}$.

El sentimiento patriótico del americano despertó o desarrolló la toma de conciencia de su identidad lingüística criolla (Frago 2010a: 293-303), de tal manera que el lenguaje campesino se fue definiendo en sus rasgos característicos de forma cada vez más completa y ordenada, la literatura gauchesca de Bartolomé Hidalgo es buena muestra de ello, entre otras cosas con el fin de incorporar las masas populares al quehacer nacional, asunto del que recientemente me he ocupado (2011). No se dejó de insistir, sin embargo, en las proclamas sobre la preeminencia de la norma de las elites y sus ventajas para el progreso de las nuevas naciones, lo que forzosamente llevaba a proponerla para una educación que se pretendía universal. Se determinarían las preferencias gramaticales y léxicas, se discutiría sobre variantes fonéticas, y las mismas reglas ortográficas se verían sometidas a una crítica reformista de alguna manera apoyada en la efervescencia nacionalista que siguió a la Independencia. De hecho, la referencia nacional y de americanidad tuvo importante peso en discursos y controversias sobre estas cuestiones, con repercusión en directrices educativas que procuraban el buen uso lingüístico, orientación pedagógica que quizá algo justificaría la afirmación de Sarmiento, no del todo falta de razón, de que "es hoy un hecho conquistado que los mejores hablistas modernos son americanos, hecho reconocido por la Academia misma" (Vergara Quiroz 1999: 524), convencimiento del que participaron varios corresponsales hispanoamericanos de Rufino José Cuervo (Romero 1992).

5 Del corpus citado en la nota 4, que en otra parte comento (2012: 86-90). 


\section{EL PORQUÉ DEL REFORMISMO ORTOGRÁFICO: BELLO Y SARMIENTO}

2. 1. En su propuesta de una ortografía para el uso americano que Andrés Bello, junto a Juan García del Río, publica en Londres en 1823 y 1826, escribe:

La Academia adoptó tres principios fundamentales para la formación de las reglas ortográficas: pronunciación, uso constante y origen. De estos, el primero es el único esencial y legítimo; la concurrencia de los otros dos es un desorden, que solo la necesidad puede disculpar. La Academia misma, que los admite, manifiesta contradicción en más de una página de su tratado (ASALE 2010a: 22) ${ }^{6}$.

Las contradicciones que Bello señalaba en la ortografía académica eran ciertas, y todavía se pueden apuntar en la norma actualmente vigente, algo por demás lógico teniendo en cuenta lo heterogéneo de tales principios. Efectivamente, el del origen es el más firme de los tres, realmente inamovible si como criterio de construcción de una ortografía se toma, pero ni mucho menos todas las etimologías son posibles o seguras en su identificación; y el "uso constante" muchas veces ha dejado de serlo, pues, por ejemplo, aver, cavallo (o cauallo) fueron grafías fonéticas corrientes durante centurias, hasta que a largo plazo, una vez perdida la distinción fonológica $b / v$, triunfó la tendencia humanística a latinizarlas, no sin resistencias hasta el mismo siglo XIX; lo mismo que solo multisecularmente se escribió sin tilde como adverbio, y ahora se ha dictado la supresión de su acento, no hace tanto tiempo establecido (cfr. 5.1.4.). Pero igual que el uso puede cambiar la pronunciación e independientemente, además, de cualquier dictado normativo, y, si no, piénsese en lo que al respecto ha supuesto el avance durante los dos últimos siglos experimentado por el yeísmo, con repercusión en su adecuación lexicográfica, incluso para el $D R A E$-por ejemplo en las entradas cholla-choya, chollar-choyar, manganilla-manganiya-, de manera mucho más llamativa en algún otro diccionario (cfr. Nota 10).

De hecho, Bello propone su reforma para una ortografía americana consciente de las dificultades que suponía la duplicidad de referencias fónicas de algunas letras, acendradas en multisecular uso, especialmente en de Bello. 
lo tocante a la sustitución de la $q$ por $c$ ante $e, i$ y a la posterior supresión de la $u$ de $g u$ en iguales secuencias, por lo que prudentemente establece dos fases para la completa aplicación de los cambios que idea, antes de que llegara "la época de adoptar este sistema en toda su extensión" (31). Sin embargo, y pasando por alto la realidad fonética que podía tener el mantenimiento de una $l l$ cuya pronunciación tradicional era por entonces desconocida para la mayoría de americanos, a su fundamental principio ortográfico no correspondía la duplicidad alfabética de la $s$ y de una $z$ "de sonido suave que le es común con la $c$ " (27), ni su pretensión de atribuir valores fónicos "en la elección de la $b$ y de la $v$, la cual no es propiamente de la jurisdicción de la ortografía, sino de la ortoepía, porque a esta toca exclusivamente señalar la buena pronunciación" $(31-32)^{7}$.

2.2. Más arriesgado se muestra en su empeño reformista Sarmiento, quien en el prólogo a su Memoria sobre ortografía americana afirma que es "cosa que interesa a todos igualmente", y que necesariamente ha de ser apropiada "para no equivocarse en la elección de las letras diversas que representan un mismo sonido de nuestro idioma hablado en América... Pero como hoy no hay uso común y constante, porque coexisten diversas maneras de escribir..., he creído que para librarnos de un golpe de los errores que a cada paso cometemos en la elección de las letras... debemos consultar el modo constante que hay en América de pronunciarlas"(2002: 9) ${ }^{8}$. Siguiendo -dice"la acertada indicación de Nebrija" y en vista de que el seseo era general, pues "si alguno duda de que el sonido $z$ y el sonido $v$ de los españoles se han perdido completamente en América..., que escuche a sus padres, si no son españoles, a su familia y a todos los que en América hablan castellano" (9-10), defiende las correspondientes simplificaciones gráficas con la eliminación de la $z$ y el empleo sistemático de la $b$.

Tuvo Sarmiento el profundo convencimiento de que la herencia española contribuía a frenar el progreso de las naciones americanas y de que era

Fernando Lolas, Alfredo Matus Olivier e Iván Jaksic, responsables de esta reedición del opúsculo ortográfico, en su nota 8 recuerdan que en otra ocasión advertiría Bello que " $b$ $\mathrm{y} v$ no se distinguen en la pronunciación, al menos son muy pocas las personas que las hacen sonar de diverso modo".

8 Según Sarmiento deberían conocer la ortografía tanto "los que se dedican a las letras", como los hacendados, los comerciantes, las mujeres y "toda persona, en fin, que tenga necesidad de escribir una carta" (ibíd.). En la edición que manejo a la Memoria ortográfica le corresponden las páginas 8-15, y por ellas se citará únicamente, como en casos semejantes, siempre que quede clara la identificación bibliográfica del texto aducido. 
la razón del desorden civil que en muchas partes se vivía, de donde sus insistentes llamadas a superar hábitos enraizados en el pasado colonial: "Por lo que a mí respecta -pondera-, he sentido agrandarse i asumir el carácter de una convicción invencible, persistente, la idea de que vamos en América en mal camino, i de que hai causas profundas, tradicionales, que es preciso romper, si no queremos dejarnos arrastrar a la descomposición, a la nada"(2002: 6). Pues bien, en la Memoria leída a la Facultad de Filosofía y Humanidades de la Universidad de Chile, el combativo autor argentino aclara la entraña ideológica y los fines que lo guían al postular una ortografía para el uso de los americanos, esto dicho como resumen a sus razonamientos sobre las letras $v$ y $z$ :

\begin{abstract}
Y si se convence al fin de que estos sonidos se han perdido en el lenguaje hablado, no use nunca en lo escrito las letras $z$ o $c e$, $c i$ ni la $v$, que no representa nada, porque nunca las usará bien, sin un grande estudio, y porque es ridículo estar usando la ortografía de una nación que pronuncia las palabras de distinto modo que nosotros, y esto precisamente en las letras cuyo uso es más difícil y nos llena de embarazos. Lo demás es estar perpetuando abusos perjudiciales, echarse la generalidad la mancha de ignorantes sin merecerla, y condenar a nuestros hijos a los tormentos que nos ha costado a nosotros aprender a leer (10).
\end{abstract}

Es decir, nacionalismo americanista en su metódica oposición a normas que juzga propias de la nación española, siempre con la referencia colonial en el pensamiento del argentino; y un criterio positivista que le hace rechazar los principios de la etimología y del uso constante recibido de la tradición, que para la Academia eran fundamentales en la reglamentación ortográfica junto al de la pronunciación, el único que Sarmiento considera racional y válido en la formación del escolar americano, para Bello asimismo, según en su primera cita se ha visto. El pragmatismo pedagógico de Sarmiento no podía por menos que repudiar académicas justificaciones ortográficas que creía arbitrarias, meras antiguallas de la vieja España incluso, para cuyo dominio se requería un esfuerzo memorístico tan exigente como estéril, pues difícilmente libraba a los americanos del error en la escritura, que podía acarrearles inmerecida "mancha de ignorantes". Esta aludida acusación de ignorancia a "la generalidad" principalmente debía tenerse por menosprecio español; y de hecho en la carta que el 15 de noviembre de 1846 escribe en Madrid a José Victorino Lastarria, cuenta Sarmiento:

A propósito, una noche hablábamos de ortografía con Ventura de la Vega i otros, i la sonrisa del desdén andaba de boca en boca rizando las estremidades de los labios. Pobres diablos de criollos, parecían disimular, 
quién los mete a ellos en cosas tan académicas! I como yo pusiese en juego baterías de grueso calibre para defender nuestras posiciones universitarias, alguien me hizo observar que, dado caso que tuviésemos razón, aquella desviación de la ortografía usual establecía una separación embarazosa entre la España i sus colonias (1997: 128)9.

2.3. En su ensayo ortográfico con indudable punto de exageración afirmaba Bello que "en la generalidad de los habitantes de América no se encontraban cinco personas en ciento que poseyesen gramaticalmente su propia lengua, y apenas una que la escribiese correctamente", atribuyendo tal estado de cosas a designio de la corte española para asegurar el sometimiento de sus posesiones americanas, pero también "consecuencia necesaria del atraso en que se encontraba España" (16). Aunque debe entenderse el sentido en que el sabio polígrafo habla de la falta de dominio gramatical de los americanos -necesariamente sería el escolarmente aprendido o el que él tuviera por correcto, y esto sin entrar en la cuestión porcentual-, creo más importante fijarme ahora en su relación de la idea de "atraso" con la ignorancia gramatical y ortográfica. Es natural, pues, que a renglón seguido Bello dejara asentado su convencimiento de que "entre los medios no solo de pulir la lengua, sino de extender y generalizar todos los ramos de ilustración, pocos habrá más importantes que el simplificar su ortografía".

Sobre el principio nebrisense, pero tampoco del todo cumplido en la obra del humanista andaluz, de que "cada letra debía tener un sonido distinto y cada sonido debía representarse por una sola letra", según Bello lo interpreta (17), el estudioso venezolano, que pronto acabaría afincándose en Chile de por vida, defenderá con firmeza la conveniencia de que "deben desterrarse

9 Y continúa Sarmiento su argumentación: "Esto no es un grave inconveniente...; como allá no leemos libros españoles, como Uds. no tienen autores, ni escritores, ni sabios, ni economistas, ni políticos, ni historiadores, ni cosa que lo valga..." (ibíd.). La aguda americanidad del polemista argentino se evidencia en esta escena madrileña, que es harto improbable sucediera en los términos que él relata, así como en el sentimiento que lo animaba al llegar a la antigua metrópoli: "esta Aspaña que tantos malos ratos me ha dado", "he venido a España con el santo propósito de levantarla el proceso verbal, para fundar una acusación, que, como fiscal reconocido ya, tengo de hacerla ante el tribunal de la opinión en América" $(127,128)$. Ya se sabe, sin embargo, que la modestia no era precisamente una de las principales virtudes de Sarmiento, pero lo que aquí importa es advertir cuánto en su compleja personalidad favorecía su designio de distanciamiento cultural de España, e indudablemente el instrumento ortográfico de la lengua poseía una gran carga simbólica, y efectiva también, en cuanto a la unidad idiomática entre españoles y americanos. Eso al menos es lo que de alguna manera Sarmiento suponía, y, de creer en su palabra, los académicos de Madrid también. 
de nuestro alfabeto las letras superfluas", fijando "las reglas para que no haya letras unísonas", bajo la primordial guía de la pronunciación, "y acomodar a ella el uso común y constante sin cuidarse de los orígenes", propuesta que, confiesa Bello, "nace solamente de nuestro celo por la propagación de las luces en América, único medio de radicar una libertad racional, y con ella los bienes de la cultura civil y de la prosperidad pública" (34).

En Bello y en Sarmiento hay un claro trasfondo de patriotismo en sus respectivos planteamientos ortográficos, evidentemente deudor el argentino del venezolano en esto, lo que algunos reproches le supuso, de simple americanidad inicialmente en el primero, también de general orientación americana en el del segundo, pero con marcados tintes nacionalistas y de rechazo a lo que entendía como dependencia respecto de España. Sentido patriótico es también el de propuestas reformistas pensadas para promover el progreso cultural, científico y económico de las nuevas naciones, facilitando un aprendizaje de la escritura guiado por la lógica de la pronunciación, con reglas más simples que en lo posible evitarían la comisión de faltas, ya denostadas en los medios más cultivados. La regularidad de las innovaciones ortográficas, el abandono de usos vistos como superfluos, y, en suma, la simplificación alfabética, eran requisitos didácticos para personalidades de tanto afán pedagógico como Bello y Sarmiento fueron.

\section{DEL DICHO ORTOGRÁFICO AL HECHO FONÉTICO: ENTRE LETRAS Y SONIDOS}

3.1. Resumiendo, "Sarmiento en esta memoria denuncia la decadencia literaria de España en ese momento y desautoriza con tono acre a la Real Academia. Se deja llevar por el violento antiespañolismo que había seguido, en las generaciones jóvenes, a las guerras de la independencia, y propone zafarse de ese «yugo impuesto por nuestros antiguos amos»" (Contreras 1991: 184), y ese ímpetu ideológico, adobado de didactismo, lo empuja a un reformismo más radical y simplificador que el de Bello. En el de este, para la segunda etapa de aplicación de su reforma tenía previsto que el alfabeto de la Academia perdiera la $c$ y la $h$, aparte de lo que de cambio suponía la reorganización de otras letras: entre $g$ y $j, i$ e $y, r r$ y $r$, amén de la supresión de la $u$ en los dígrafos $g u, q u$. En el repertorio del argentino se contemplaba la poda de $h, q, v, z$ y $x$.

Pero no fueron Bello y Sarmiento los únicos reformadores que en materia ortográfica conoció el mundo hispánico durante la primera mitad del siglo 
XIX, aunque por razones no siempre idénticas, variables sobre todo en el trasfondo ideológico que a sus proponentes guiaba, y generalmente uniformes en cuanto a finalidad didáctica. Intención netamente pedagógica, aparte de lo que de falta de aprecio al prestigio y autoridad intelectual de la Real Academia suponía, declara la Academia literaria y científica de profesores de instrucción primaria de esta Corte en el proyecto que publica en El Eco del Comercio de Madrid el 21 de abril de 1843, donde se demanda la eliminación de las letras $h, v$, y $q$, esta sustituída por la $c$ en cualquier secuencia de la escritura, y de la $u$ en los dígrafos $q u$ y $g u$ ante $e, i$. Semejanzas, por tanto, con la propuesta presentada en 1844 a la Universidad de Chile por Sarmiento, que saluda alborozado el plan español, hecho también bajo el criterio de la pronunciación, aunque queriendo dejar a salvo la originalidad del suyo.

Y ciertamente hubo otras propuestas de reforma ortográfica en América, unas conocidas y otras que probablemente se irán descubriendo, pues el problema interesó a muchos en muchas partes. El mismo Bello en 1827 reprodujo un artículo publicado en el periódico mexicano El Sol el 15 de julio de 1824, que podría tomarse como un precedente más del proyecto reformista de Sarmiento, donde no se suprime la $z$ de pronunciación peninsular, en coincidencia con Bello y a diferencia de la decisión que el sanjuanino tomaría años después, y en febrero de 1844 dos periódicos chilenos, El Mercurio y La Gaceta del Comercio, sacan un texto de reforma ortográfica antes aparecido en El Siglo de México, cuyo autor, Jacobo Villaurrutia, apostaba por cambios en su mayor parte coincidentes con los que Sarmiento preconiza, suprimiendo las letras $c, z, k(\mathrm{o} q), v, x$, y la $l l$ sustituída por $y$ (Verdevoye 1988: 205). Advierte, así, Sarmiento que en España, México y Chile hay acuerdo - pero se notará que solo desde los mencionados proyectos y el de su autoría- para el abandono de $h, x, v, q, k$, letras consideradas inútiles, y que en los dos países americanos se propugna la desaparición de la $z$ del alfabeto, viendo de esta manera apoyada su postura por los artículos ortográficos de la Academia de maestros madrileños y de Villaurrutia (Verdevoye 1988: 204).

3.2. Sin embargo, ni el criterio de la pronunciación moldeó toda la ortografía nebrisense ni podía conformar plenamente las de los reformistas decimonónicos, aunque sí ayudara a simplificar la mantenida por la Real Academia Española, que, con variantes conocidas por aquel que esté familiarizado con los textos de la época, se hallaba extendida por todo el mundo hispánico, como continuación que era de buena parte de los usos grafémicos más usuales en nuestra tradición escrituraria. Había, pues, motivos para los intentos reformistas en aquel preciso contexto ideológico y educativo, pero también no pocos obstáculos en contra de su triunfo, 
y algunos estaban en su mismo germen doctrinal, empezando por la dificultad de adecuar estrictamente el alfabeto a la pronunciación, principio fundamental de aquellos reformadores, cuando en la época todavía no era absolutamente común la perfecta distinción entre letra y sonido en quienes se ocuapaban de cuestiones literarias y lingüísticas. Y esto puede ejemplificarse en el tratamiento ortográfico que se dio al yeísmo.

Efectivamente, no manifiesta tal distinción en este punto el anónimo Catálogo de 1843 cuando su autor advierte que "se dice" balloneta, gayeta, rayo y recomienda decir bayoneta, galleta, rallo (Ferreccio Podestá 1979), casos en los que debería haber advertido "escríbase". Ni siquiera Andrés Bello consiguió librarse del todo de la confusión en el siguiente párrafo de sus Advertencias sobre el uso de la lengua castellana, llevado quizá de un afán reglamentista contrario a las faltas que en el uso de este par de letras propiciaba la pronunciación yeísta: "los que se cuidan de evitar todo resabio de vulgarismo en su pronunciación procuran no equivocar... la $y$ con la $l l$, confundiendo haya, tiempo de haber con halla, tiempo de hallar" (ASALE 2010a: 59). Hasta tal punto, que llega a aconsejar la correspondiente distinción fonética al querer inculcar el empleo diferenciado de "la $s$ de la $z$ o la c" para conseguir "una pronunciación más esmerada", necesariamente la propia de los peninsulares, o un fonetismo artificioso para lograr el uso sin errores de la $b$ y la $v$. En él prima entonces el deseo de inculcar en la educación la corrección ortográfica a costa de introducir en la enseñanza coerciones de discutible didactismo, en todo caso ajenas a la fonética americana.

Al rechazar el antihiatismo de segundo grado, "no debe decirse... sandiya, sino sandía", resultante en epéntesis consonántica, coincide Bello (ASALE 2010a: 60) con el anónimo redactor del citado Catálogo, solo que este, aparte de la solución por traslado acentual, sándia, el epentético vulgar lo escribe sandilla, con mero y evidente lapsus ortográfico, por lo demás de probado arraigo documental: reiteradas presencias de sandilla encontré en manuscrito chileno de 1808-1817 (2010b: 121), y zandilla en corpus peruano de finales del XVIII (1999: 210). El trueque de $z$ - por $s$ - desde luego se debe al fonetismo seseoso, como el de $l l$ por $y$ está causado por la pronunciación yeísta, exactamente igual que cuando en lugar de yendo pone llendo el editor moderno en su anotación a una carta de Sarmiento: "Desde hacía algunos años huía del invierno bonaerense llendo primero a Tucumán y después a Asunción del Paraguay" (Vergara Quiroz 1999: 203). Son las faltas típicas de quien sesea o no tiene $/ \lambda /$, como, mejor que cualquier tratado, explican estos versos dedicados a Cuervo en 1889 por el escritor peruano Pacheco Zegarra (Romero 1992: I, 369): 
por alboroto, bochinche,

le pongo elle a papagayo;

y aunque me tomes por payo,

hago masculino a chinche,

y gayo digo y cabayo

Así, pues, tanto zandilla como sandilla no representan sino la pronunciación /sandíya/, las dos formas con lleísmo gráfico y la primera con su cacografía inicial causada por el cruce entre el seseo del hablante y su manejo ortográfico, y este desliz originado en el yeísmo fonético debió de ser frecuente en la escritura colonial y de la América independiente, pues tan flagrante falta ha conseguido introducirse en algunas fichas eruditas, a tenor del indebido acomodo que sandilla ha encontrado en el académico diccionario de americanismos (ASALE 2010b) ${ }^{10}$.

Bello no podía caer en la burda confusión cacográfica de sandilla, y menos atribuirle el valor fónico que aparenta, al contrario de lo que le ocurrió al autor del Catálogo de 1843, quien anota "se dice sándia, sandilla" y recomienda "dígase sandía" (Ferreccio Podestá 1979: 57), pues el sabio polígrafo sabía bien cuál era la pronunciación de la /y/y su correspondencia ortográfica $(y, i)$, aparte de que, según su advertencia normativa prueba, asimismo le resultaba familiar la voz epentética, que todavía "se da en todo el país, desde Punta Arenas hasta Iquique, principalmente en el lenguaje rústico, que conoce también la forma sandiyar" (Oroz 1966: 87). Con todo y con ello, no prescindió Bello de la $l l$, que ni siquiera respondería a su condición de hablante, muy probablemente yeísta, orillando en este caso el principio de la pronunciación a favor de la "autoridad de la costumbre", y en cierto

10 Donde se ha admitido sandilla, sandillal con referencia a El Salvador y Costa Rica, sandillar como poco usado en Perú y rural en Chile, y en cambio no recoge el verídico sandiya, usual en distintas partes de América y en las mismas hablas chilenas, como a continuación con la autoridad de Orozco se indica; también sandilla, "vulgarismo pocho", y sandillita "planta cucurbitácea, que produce un frutecillo del mismo nombre..., jaspeado de blanco sobre el verde, liso, de sabor de pepino' (Santamaría 1978: 959). Son en este diccionario académico demasiado frecuentes entradas dobladas como las de chullo-chuyo, yapar-llapar, llocallayocalla, hallaca-hayaca, llantén-yantén, etc., con algún lleísmo gráfico más (así jullido, jullirse, de juyir, epéntesis antihiática de juir 'huir'), sin que falten no pocos dobletes relacionados con el seseo, es decir unas mismas palabras escritas con $s$ y $c-z$. Por cierto, las mismas Academias, ahora también con el sello de la Española, en obra inmediatamente posterior solo recogen sandiya, y no sandilla, curiosamente con geografía muy centroamericana, pero con escasa atención a su difusión por el resto de América, y con referencia sociolingüística, ya que del caso de Costa Rica se habla, en conjunto incompleta (ASALE y RAE 2011:354). Y me parece harto discutible que los hablantes usen "estrategias para eliminar los hiatos", como el redactor de este apartado dice. 
modo también ateniéndose al predicamento de la "buena pronunciación" o de "una pronunciación más esmerada", que en este punto, y en el tocante a la distinción de $s$ y $z$, sin nombrarlo refería al español de España. Y Sarmiento, a pesar de afirmar sin ambages que "es ridículo estar usando la ortografía de una nación que pronuncia las palabras de distinto modo que nosotros", de asumir con entusiasmo "la acertada indicación de Nebrija" (cada letra su sonido, cada sonido su letra, según su interpretación), y de rechazar dialécticamente tanto el criterio de la etimología como el del uso constante, identificado con el mantenido por "la actual nulidad de la Academia de la lengua española", mantendrá en su propuesta reformista y simplificadora tanto la $l l$ como la $y$.

Es poco probable que el sanjuanino no percibiera la diferente pronunciación de $l l$ y de $y$ de los distinguidores, su fino oído y aguda curiosidad le hacen notar el "silbar la $s$ y prolongarla indefinidamente en las finales" del actor español Fedriani (2002: 10), no obstante que, según un autor anónimo, en Argentina "se pronuncia yover y no llover" (Verdevoye 1988: 202), algo que en 1817 afirmaba el gramático Antonio J. Valdés, como Guitarte recuerda (cfr. 5.4.), y que seguramente él mismo fuera yeísta. De hecho, en su relato Fiestas de la Noche Buena se registra un caso de confusión, "las calles tapadas de gente de chupaya que marchaba en todas direcciones", con $y$ por $l l$, y otro de $l l$ por $y$ precisamente con sandilla: "oí pregonar duraznitos de la Virgen, porotos granados..., cirgüelas por cierto, sandillas..." (2002: 126, $128)^{11}$. El yeísmo de chupaya, del quechua achupalla, no parece marcado de connotación extralingüística alguna, mientras que el lleísmo gráfico de sandilla, sobre el epentético sandiya, tal vez esté intencionadamente puesto para matizar más el cuadro popular que Sarmiento describe, con una forma cacográfica rechazada de la escritura en aquellos años por los cultos y por la normativa que los representaba.

11 Cfr. n. 10. También se rechaza cirgüela en el Catálogo de 1843 (Ferreccio Podestá 1979: 47). El diccionario de la ASALE (2010b: 27, 582, 583), recoge en distintas entradas chupalla 'sombrero de paja', localizado en Chile y noroeste de Argentina, en Perú y Chile también como nombre de la planta de cuyas hojas se fabrica el sombrero (en otra achupalla para Ecuador y Perú), y chupaya 'sombrero de ala ancha hecho con tirillas de paja', asimismo localizado en el noroeste argentino, y, evidentemente, una mayor coherencia lexicográfica sería aquí exigible. La segunda cita de Sarmiento arriba aducida lleva esas cursivas en la edición de la que la tomo. 


\section{EL PESO DE LA OPINIÓN PÚBLICA. OTRAS CONSIDERACIONES}

4.1. Las reformas ortográficas emprendidas tras la independencia de América tuvieron sus razones de ser, una objetivamente didáctica, cual era la búsqueda de un alfabeto más simple y adecuado a la enseñanza de la escritura, fin que persiguió el proyecto de la Academia madrileña de profesores de instrucción primaria en 1843, y otras ideológicas, no siempre con precisión declaradas, que entre los americanos condicionaron la pedagogía en materia de escritura con innegable origen en la independencia política, y en Sarmiento con la franca intención de añadir un motivo más de emancipación cultural respecto de España. Y, sin embargo, ninguno de aquellos intentos reformadores triunfó con las pretensiones de aplicación general con que se idearon; el de Sarmiento la Facultad de Filosofía y Humanidades de la Universidad de Chile lo aprueba en abril de 1844, pero prácticamente rebajado a los términos en que formuló el suyo Bello en Londres el año 1823. Se conservaban las letras $x, v$ y $z$, estas dos radicalmente contrarias al designio ortográfico del emigrado argentino, y además la decisión de la Facultad no fue imperativa, pues pronto comunica a los integrantes de su claustro "qe los miembros qe no estubieren de acuerdo con las decisiones eran libres de usar la ortografía qe tubieren a bien" (Verdevoye 1988: 204-205).

Aún así, esta ortografía americana apenas tres años se practicó, sin que en ese tiempo ni mucho menos llegara a hacerse exclusiva en el mismo Chile, y el propio Bello cancelaría en 1851 la reforma que pocos años antes como Rector había sancionado. El Araucano, por él dirigido, ya había desertado de esta reforma desde junio de 1847, los Anales de la Universidad desde el tomo tercero del mismo año, y Sarmiento, el revolucionario del alfabeto, como fue llamado, hizo lo propio al regreso de los viajes que había emprendido entre 1845 y 1848 . A partir de entonces solo continuó en uso la que se daría en llamar "ortografía de Bello" - la y únicamente con valor consonántico, $i$ en cualquier posición para $/ \mathrm{i} /$, y la $j$ velar constante ante $e, i-$, y muchos prescindieron de la $x$ ante otra consonante a favor de la $s$ (estraordinario), en conjunto con la conocida como ortografía chilena o casera. Hacia $1884 \mathrm{se}$ reanudaría la polémica "con diversos proyectos y contraproyectos, hasta que en 1927, el 12 de octubre y como homenaje a la madre patria, se implantó en el país la ortografía académica por decreto supremo" (Contreras 1991: 187). Nada se salvaría, pues, de la aventura reformista iniciada por Bello en 1823. 
4.2. Chile fue el principal reducto de la reforma ortográfica en América, apoyada en el prestigio de la descollante figura de Bello, desde su llegada a Chile de Londres, donde la había diseñado; proyectada luego en términos más radicales por Sarmiento, quien defendió su plan con ardor dialéctico y agudeza argumentativa. Sin embargo, ni el afán que la recia personalidad del argentino puso en el empeño pudo evitar su fracaso, una de cuyas causas seguramente fue la inquietud que a muchos movió su excesiva simplificación ortográfica, demasiado chocante con los usos tradicionales. De ahí la prudencia de la Universidad chilena al rebajar la propuesta de Sarmiento hasta las normas más moderadas de Bello, incluso aligerando los preceptos de este. La obra del insigne caraqueño influyó en los medios cultos de Hispanoamérica, no solo por su aportación gramatical y orientación normativa, de manera que no extraña que hallaran eco fuera de Chile sus propuestas ortográficas (Deas 1993), inevitablemente acompañadas de la polémica.

Tropezaban las reformas ortográficas americanas con obstáculos de no pequeña entidad, empezando por las encendidas controversias que suscitaron, sobre todo cuando Sarmiento extremó el contraste con los usos establecidos en la tradición escrituraria, con tintes vindicativos frente a la que trataba de ortografía española por el criterio fonético, cuando en España no todos tenían las pronunciaciones correspondientes a $l l$ y $y$, a $s$ y $c-z$. Muchos reparos recibió el plan del reformador argentino, algunos peligrosos para la aceptación de su proyecto, así el de que sería necesaria la enseñanza de dos sistemas ortográficos a fin de que los niños pudieran leer los textos escritos con el tradicional, y el de que aquella ortografía americana pondría en peligro la unidad del idioma, a lo que Sarmiento argumentó que los idiomas cambian aunque no se modifique su ortografía (Contreras 1991: 186-187). El supuesto de la posible fragmentación del español por la diversidad ortográfica fue por entonces materia de debate, y los propios académicos españoles mantuvieron la especie, a tenor de lo que Sarmiento refiere a Lastarria en su carta madrileña (cfr. 2.2. y nota 9). Más tarde, ya abandonado en buena parte de América cualquier intento de particularismo ortográfico, se suscitaría la agria polémica entre Cuervo y Valera sobre si habría una desagregación dialectal del español, "la disolución del idioma", como el cubano Rafael M. Merchán dice al filólogo colombiano en la solidaria carta que le escribe en Madrid el 7 de mayo de 1903 (Romero 1992: II, 230).

4.3. Hubo opiniones radicalmente hostiles al reformismo chileno, también favorables, desde el momento en que la propuesta de Sarmiento fue presentada a la institución universitaria y aprobada en versión próxima 
al proyecto de Bello, y así Herrera Dávila y Alvear en el prólogo de su gramática defienden el "método invariable y uniforme de escribir", pues "nunca es dado a hombres aislados el hacer una reforma de esta naturaleza, por carecer de todo el influjo necesario en la opinión pública", por lo que "esta gloria está reservada a la respetable Academia Española, establecida principalmente para enriquecer y mejorar nuestra lengua" (1845: XII) ${ }^{12}$. El respeto de estos gramáticos a la autoridad de la Real Academia Española en otros por entonces era desdén, nada digamos en Sarmiento, y pasado el tiempo aún habría juicios como los expresados por el citado Penson en 1891: "ese criterio de autoridad es letal, ejercido por un cuerpo que no tiene más que la tradición que alegar", "el último (diccionario) de la Academia inspira aversión, y nadie le hace caso" (Romero 1992: II, 263, 264).

Sin embargo, más allá de filias y fobias académicas, lo que a mi juicio resultó decisivo contra el triunfo de las reformas americanas fue una cuestión práctica, por lo que de cultural y extralingüístico, o de simple continuidad de usos acendrados por la tradición, también tiene la ortografía. La representación gráfica de un sonido puede mantenerse o cambiarse, se puede usar la $h$ o prescindir de ella, y tras la pérdida de la oposición fonológica $/ \mathrm{b} / \sim / \mathrm{v} /$ fue posible conservar las letras $b$ y $v$ (incluso $u$ ), que respectivamente habían sido de cada unidad del transformado par fonemático $(/ \mathrm{b}, \mathrm{v} />/ \mathrm{b} /)$; de hecho, esto era lo más cómodo por responder a la inercia escrituraria, o se podía optar por el empleo de una sola letra del único fonema resultante: pero ¿por qué $b$ y no $v$ ? Lo extraordinariamente difícil era conseguir amplios apoyos sociales para la reforma cuando tantos sentimientos y arraigadas costumbres se veían tocados y tan ruidosa la controversia en la opinión pública. No solo eso, sino que la ruptura con los usos tradicionalmente establecidos debía aplicarse a la enseñanza escolar y afectaba seriamente a la industria editorial, con repercusión social y conflictos que ninguna ortografía innovadora de los siglos XVI-XVIII, piénsese en las de Mateo Alemán y Gonzalo Correas, en absoluto conoció. De hecho, una vez aprobado el proyecto de Sarmiento con los cambios que limitaban su inicial planteamiento rupturista, unas publicaciones siguen el dictamen de la Facultad de Filosofía y Humanidades, otras lo rechazan y en otras la

12 El ejemplar consultado se guarda en el Archivo Central Andrés Bello de la Universidad de Chile: ref. 75/1774/299. En esta gramática $c$ y $z$ tienen definición articulatoria, así como la $l l$ y la $y(112,113,115)$. Influencia claramente española muestra asimismo el epítome gramatical de Juan Nicolás Noé (1837), quien inicialmente reconoce que "el presente opúsculo puede llamarse un compendio de la escelente gramática de D. Vicente Salvá": en la misma biblioteca chilena (ref. 818/48). 
novedad y tradición conviven, aunque "en su mayoría los impresores hacen ascos a la reforma" (Verdevoye 1988: 205).

4.4. Era consciente Bello de los problemas que encontraría su plan de simplificación y uniformación ortográfica en América: "No tenemos la temeridad de pensar que las reformas que vamos a sugerir se adopten inmediatamente. Demasiado conocemos cuánto es el imperio de la preocupación y de los hábitos" (ASALE 2010a: 16-17). Acabarían imponiéndose, en efecto, los usos recibidos de la tradición hispánica, acendrada por una extraordinaria creación textual, que nunca dejaron de aplicarse en todos los dominios del español. Otra cosa son las variantes, pero todas las propuestas de Bello, y casi todas las de Sarmiento, tienen antecedentes en la escritura española y americana, aunque por entonces no con la sistematicidad con que él las planteó; estas variantes eran las grafías que lentamente a lo largo de siglos se habían orillado, y las confusiones ortográficas, en buena medida resultantes de la evolución fonética, que muchos con diversa frecuencia cometían (cfr. 5.3.).

Estas faltas se habían prodigado anteriormente tanto en las Indias como en la metrópoli, fruto "de la mala enseñanza o de la inexacta instrucción en los principios", en palabras de Bello (23), porque el impulso regulador que pudiera emanar de la Real Academia tenía limitada eficacia y ni mucho menos llegaba a todos los rincones del vasto mundo hispánico donde se enseñaban las primeras letras, en los cuales el "cada maestrillo tiene su librillo" era hecho habitual. Ahora bien, la "variedad" de la escritura española consistente en confusiones como las de $b$ y $v, c$ y $q$ o $j$ y $g$, que al sabio venezolano preocupaba, podía llevar a evitarlas mediante procedimientos pedagógicos aplicados al sistema existente, que era tan español como americano, o a simplificarlo a fin de facilitar su enseñanza, lo que él se propuso. Sin embargo, Sarmiento, sin duda no por ignorancia sino para llevar el agua a su molino argumental, desenfoca la realidad cuando escribe: "Pero como hoy no hay uso común y constante, porque coexisten diversas maneras de escribir, y necesitamos adoptar una ortografía cualquiera..." (2002: 9).

No obstante lo que parece desprenderse de sus palabras, había una ortografía de uso común, tan metropolitano como ultramarino, de bastante uniformidad ya antes de la fundación de la Real Academia Española, en la que a uno y otro lado del Atlántico se había escrito un mundo de letras, y la institución académica en sucesivas ocasiones a lo largo del siglo XVIII y principios del XIX había ido reformándola con lenta prudencia, y sus cambios asimismo se recibieron en América, aunque con ciertos retardos, perfectamente explicables. Bien lo sabía Bello, quien reconoce que las 
reformas introducidas por la Academia se habían adoptado "tanto en la Península como fuera de ella" (18). El uso constante o "autoridad de la costumbre" en la práctica era de españoles y americanos por igual, como sus desajustes por la continuidad de variantes arcaicas fuera del canon ortográfico, así como los lapsus cálami en el empleo de sus reglas. Pero la tolerancia de que las faltas ortográficas habían gozado, de alguna manera incluso en medios culturales selectos, desapareció en un siglo en el que se asociaron al nivel más popular e inculto y se sintieron contrarias a la mejor educación y al progreso nacional.

4.5. La corrección ortográfica se convirtió en importante faceta de la normatividad lingüística y en meta de la política educativa, denostada la impericia en su uso como estigma cultural; pero los lapsus no eran tan fáciles de evitar, ni los eliminaría de golpe el sistema defendido por Sarmiento, contra lo que en la presentación de su proyecto creyó, pues también se cometieron errores con la ortografía reformada, inevitablemente cruzada con la tradicional que todos habían manejado. Especialmente pugnaces eran las faltas relacionadas con el seseo y el yeísmo, siempre lo han sido para quienes tienen estas pronunciaciones, y para impedirlas o dificultarlas, junto a las otras que más recurrentemente se cometían, se llegó a recomendar al criollo la pronunciación del peninsular. Antes de iniciarse los movimientos independentistas, el año 1808 en un periódico bogotano se tachaba de barbarie, que también se daba "entre personas instruídas", el no observar "tanto en el lenguaje como en la escritura" los preceptos de la prosodia, "y el motivo de ser todos los americanos bárbaros, respecto de la pronunciación de nuestro común idioma", era que "las letras $l l, c, z, v, \mathrm{y}$ otras, no tienen en los naturales de la América el sonido puramente castellano", lo cual "es una notable falta". El autor del artículo, siendo americano, es partidario de adoptar la fonética española para resolver la conculcación ortográfica, plenamente consciente, sin embargo, de la inutilidad de cualquier intento en tal sentido:

¿Y quién tendría valor para emprender esta reforma, dando por sí mismo el exemplo? ¡Infeliz, morirías rabiando a fuerza de zumbas, solo porque te metiste a hablar el castellano puro, sin haber nacido en los Reynos de Castilla! ${ }^{13}$

13 El Redactor Americano. Periódico del Nuevo Reyno de Granada, núm. 28, 19 de enero de 1808, 124-125: Biblioteca Nacional de Colombia, ref. VFDU1-297, y en línea http://www. bibliotecanacional.gov.co/?idcategoria $=38347$. 
4.6. Esta "reforma" efectivamente era imposible, pues no trataría simplemente de ortografía, sino de imponer a los americanos pronunciaciones ajenas a fin de combatir las confusiones ortográficas; pero la corrección ortográfica solo con apropiado método pedagógico y disciplina escolar podía intentarse. Bello no solo defenderá la necesidad de una nueva educación en América y el importante papel que el lenguaje había de jugar en ella, sino que, en consonancia con este principio, procura simplificar la ortografía existente para facilitar la enseñanza y el aprendizaje de la escritura. Proclama el principio de la pronunciación, pero no se rige por la de los americanos manteniendo la $z$ y la $l l$, y propone una diferenciación fonética ajena a los hablantes para cuidar la distinción $b$ y $v$. Cuando conserva la $z$ en su reforma de alguna manera está siendo condicionado por el español de España, con mayor claridad cuando en sus Advertencias sobre el uso de la lengua castellana habla de "una pronunciación más esmerada" en los que distingan "la $s$ de la $z$ o la $c$ " (ASALE 2010a: 59), afección que otros sintieron de manera un tanto confusa, porque sonidos y letras se solaparon durante mucho tiempo. El dominicano Penson, despectivo hacia la autoridad de la Academia española, en 1891, aun ensalzando la norma americana, todavía valoraba "la buena dicción castellana" (cfr. 5.4.).

Sarmiento pretendió adecuar la ortografía a la realidad lingüística americana de acuerdo con el criterio de la pronunciación; pero si suprimió la $z$, conservó la $l l$ : más consecuente en esto fue, pues, el proyecto mexicano de Villaurrutia. Había advertido Bello contradicciones en la ortografía tradicional que con sus retoques abanderaba la Academia española, pero no deja de ser también una contradicción la preservación de la $l l$ en reformas dirigidas a dominios yeístas, mayoritarios por entonces en el conjunto americano: ese afincamiento en el multisecular arraigo de la $l l$ aparte de contradecir el principio de la pronunciación y de suponer un inconfesado respeto, ¿inadvertido acaso?, a la "autoridad de la costumbre" o "uso constante", asimismo responde al "fetichismo de la letra" que en otros casos ortográficos advirtió Rosenblat (1971: 41-81) ${ }^{14}$.

\footnotetext{
14 Fenómeno manifestado no solo en la presión extralingüística que animó a los mexicanos a oponerse a la supresión de la $x$ con valor velar, que había dispuesto la Academia española, sino también en la tenaz resistencia que la simbólica $y$ en España y América opuso a su total eliminación a comienzo e interior de palabra, o en el intento, más pronunciado en las naciones americanas, de cargar de valor fónico la $v$ en la enseñanza, sobre todo para así evitar su confusión con la $b$ en la escritura.
} 


\section{DEL IMPULSO REFORMISTA A SU FRACASO}

5.1. Aunque no fueron las contradicciones, ¿qué ortografía no las presenta y aspectos discutibles?, las que impidieron el triunfo de este reformismo. La ortografía de la Real Academia Española en lo fundamental era y había sido la de todos, y sus textos, de la época e históricos, también de obligada lectura entre las minorías cultas de España y de América. Y los cambios en esta materia, no ya los de sistema sino incluso los puntuales, desde luego no son cuestión de pocos años en su universal aceptación. No hay más que ver lo que en la práctica ha sucedido con los presentados en las varias ediciones de la ortografía académica, ninguno de inmediata generalización, ni siquiera los que últimamente se han propuesto en cuanto a acentuación y otros, aun siendo de escasa entidad y poderosos los actuales medios de comunicación.

5.1.1. Efectivamente, en la penúltima Ortografía académica respecto de la tilde diacrítica en solo se prescribía que únicamente "cuando quien escribe perciba riesgo de ambigüedad, llevará acento ortográfico en su uso adverbial", y, con discutible criterio lingüístico, de vocablos como fié, hui, riáis, guión se dice que "a efectos ortográficos, son monosílabos" y "se considera que no existe hiato -aunque la pronunciación así parezca indicarlo-, sino diptongo o triptongo", inacentuados por tanto, si bien "en este caso es admisible el acento gráfico, impuesto por las reglas de ortografía anteriores a estas, si quien escribe percibe nítidamente el hiato $y$, en consecuencia, considera bisílabas palabras como las mencionadas" (RAE 1999: 46, 51). No obstante que el texto académico, consecuente con la doctrina que en él se establece, sistemáticamente pone sin tilde solo y guion, dejaba la innovación ortográfica al arbitrio de la "percepción" fonética de "quien escribe", con lo que de innumerable variación en la letra manuscrita e impresa esto podía suponer. En la siguiente normativa se justifica por el principio de la pronunciación la reciente decisión sobre solo, que así se expone en manual escolar, el que mayor impacto normativo está llamado a tener: "ese empleo tradicional de la tilde no cumple el requisito fundamental que justifica el uso de la tilde diacrítica, que es el de oponer palabras tónicas a otras formalmente idénticas, ya que tanto solo como los demostrativos son siempre palabras tónicas en cualquiera de sus funciones", concluyendo que "por eso, se podrá (la cursiva es mía) prescindir de la tilde en estas formas incluso en casos de ambigüedad" (RAE y ASALE 2012: 54-55). En esta edición ortográfica las Academias a las otras voces aquí consignadas (fiais, fie, guion, hui, lieis, etc.) las considera monosílabas de "diptongo 
ortográfico", ya con tajante regla de no acentuarlas, sin la permisividad que antes se concedía a la costumbre (38-43).

5.1.2. Se observa aquí cómo los criterios ortográficos son susceptibles de cambio y no siempre de fácil justificación, pues si en el Prontuario elaborado a consecuencia de la concesión por Real Orden de 1844 del monopolio normativo, "prohibiendo que en las escuelas públicas del Reino se enseñase otra Ortografía que la adoptada por la misma Academia", se fijaban como sus fundamentos dos principios, "el origen de las voces, y la alteración que en muchas de ellas ha introducido el uso, que es el árbitro supremo de las lenguas" (RAE 1857: 5, 6), estos principios han sufrido una importante modificación en la última reforma, el primero de ellos sobre todo. Porque, por el origen, fiáis, fié, guión, huí, liéis, etc., son sin género alguno de duda bisílabos, y como bisílabos se han pronunciado siempre, hasta hoy en parte del mundo hispánico. Ahora bien, "la alteración que... ha introducido el uso" ha hecho que se pronuncien monosílabos en otros dominios y, "debido a esta doble articulación y con el objetivo de preservar la unidad ortográfica", según otro corpus normativo de las Academias argumenta, "se establece que toda combinación de vocal cerrada átona y abierta tónica se considere diptongo a efectos de acentuación gráfica" (RAE y ASALE 2005: 323).

5.1.3. La lengua cambia, en efecto, pero también la percepción que los hablantes, sobre todo los de la minoría culta, tienen de su variación a lo largo de la historia, pues no son pocos los fenómenos durante un tiempo tenidos por vulgares que han perdido esa negativa connotación, como en muchos sitios ha ocurrido con la pérdida de la /-d-/ en - ado, hoy tan extendida en todos los estratos sociales de buena parte de España, o con el mismo antihiatismo, de siempre existente en nuestra lengua, pero durante siglos limitado al nivel popular. Lo rechazaban con rotundidad en América, prueba de lo extendido que el modismo fonético se hallaba, quienes de una u otra manera del lenguaje trataban, ya antes de la Independencia; así, en Bogotá un periódico el año 1808 advertía que pronunciar "cáya por caía, óydo por oído", y "país que por lo común pronuncian páys", no era propio de "todos los patricios de esta ilustre capital...; así habla el estado común, pero sería mentira atribuírselo a la gente visible y de fina educación" ${ }^{15}$. En 1889 escribía Pacheco Zegarra a Cuervo una composición, de la que algunos versos arriba se ven citados, con rasgos del que, dice, "además, es chabacano / mi lenguaje americano",

15 En el lugar citado por la nota 13. 
crítica, pues, a la variedad popular, entre los cuales consigna la alteración antihiática: "ráices digo por raíces", "falta un cuarto para láuna" (Romero 1992: I, 368, 369, 370). Y antes lo condenaron el autor del Catálogo chileno de 1843: "se dice Juaquín, dígase Joaquín", "se dice pión, dígase peón", "se dice sándia, sandilla, dígase sandía", etc. (Ferreccio Podestá 1979: 52, 55, 57), y mucho énfasis puso Bello en su rechazo en las Advertencias sobre el uso de la lengua castellana, donde entre lo que "no debe decirse" están sandiya, cáido, pronunciar cáer, tráer, réir o cáia, léia, réia, las sinéresis crer, cremos, y las hipercorrecciones cambeo, vaceas, peano por cambio, vacio, piano (ASALE 2010a: 49, 60).

Evidentemente, desde entonces el antihiatismo ha ganado espacio en América, introducido ya en medios sociales que en otro tiempo lo rechazaron, pero no en todas partes ni en todos los países con exclusividad, manteniéndose aún en no pocos sitios diferencias sociolingüísticas respecto de su uso, como por lo demás ocurre en España, donde popular y vulgarmente el antihiato es bien conocido, con diferencias regionales. Nada de particular tiene que el uso que en un determinado dominio entre ciertos hablantes se consideró inculto haya pasado a ser corriente y normativamente aceptado por sus sucesores, socioculturalmente hablando, en la variedad antihiática referida ${ }^{16}$. Ahora bien, el argumento de la "doble articulación" y de la expansión del antihiato en América, cuando dista mucho de ser general, aparte de lo que sobre el particular corresponde al español europeo, por las Academias esgrimido como justificación para la supresión del acento ortográfico en guión o fié, "con el objetivo de preservar la unidad ortográfica", resulta inquietante, pues mayores razones estrictamente lingüísticas, demográficas y territoriales hay para extender la reforma a otros usos ortográficos. Claro es que en tal caso los conflictos de todo orden serían mayúsculos, y no ha sido pequeña, aunque quizá pasajera, la controversia que estos cambios de las Academias, nimios en verdad, han suscitado, incluso con el repudio público a los mismos de algunos académicos españoles y la inobservancia de otros a alguna de las recientes novedades normativas ${ }^{17}$.

16 No en las que resultan en realizaciones como oíya, sandiya, o aura 'ahora', maistro.

17 Todo lo cual es fácilmente constatable en la lectura de semanarios y otros medios periodísticos. Contrario se muestra asimismo Seco a la eliminación de la tilde en guión, y similares casos, "la Academia está errada - dice-, y siembra con ello la confusión", argumentando en su crítica a los términos en que la regla académica se establece (2011: 687). En cuanto a solo, las Academias en su tratado panhispánico dictaminan que "cuando esta palabra pueda interpretarse en un mismo enunciado como adverbio o como adjetivo, se utilizará obligatoriamente la tilde en el uso adverbial para evitar ambigüedades" (RAE y ASALE 2005: 639), y Seco arguye que "en realidad, la ambigüedad no tiene por qué 
5.1.4. Si me he detenido en esta cuestión es con el intento de enjuiciar sin anacronismo el problema del reformismo ortográfico americano de la primera mitad del siglo XIX, pues por un lado en los últimos retoques normativos se advierte cómo la costumbre o el uso constante se puede soslayar, aunque pese mucho en la práctica, recuérdese el permisivo se podrá prescindir de la tilde referido a solo; de ahí las concesiones a la "interpretación" del que escribe, y cómo el criterio fonético, aun limitado al tildado de voces con hiato y con su solución diptongada, no es de aplicación sin reservas en un mundo tan ancho y variado como el de la lengua española. Pero, por otro lado, el adverbio solo durante siglos no se acentuó, no lo tilda el Autoridades, y tardaría mucho hasta que, desde 1925 , en los diccionarios académicos ${ }^{18}$ se le pusiera el signo diacrítico para "distinguirlo" de solo adjetivo: de un uso constante se pasó a otro, que ahora se cambia para volver a los orígenes. El criterio es lógico en la moderna ortografía, pues la voz es llana como adjetivo o adverbio, y termina en vocal, y supuestamente lo más fácil es no acentuar; sin embargo, transcurridos trece años desde 1999, en la escritura de los particulares parece predominar aún la norma precedente, y en general también es lo que sucede en muchos periódicos españoles y americanos. Desde luego no he leído ninguno en el que haya un absoluto acatamiento a esta innovación, cuyo triunfo sin duda requerirá bastante tiempo, sobre todo si en la enseñanza escolar no se sigue con todo rigor ${ }^{19}$.

\subsection{Que los criterios aplicados a la normatividad ortográfica sean mudables} y que, siendo varios, puedan resultar difícilmente ajustables entre sí cuando se pone en marcha el procedimiento de una reforma, nada de extraño tiene en materia de tanta complejidad como la ortográfica es; ni siquiera que sea posible la arbitrariedad en su tratamiento, sea individual o corporativo. La

presentarse nunca, porque el contexto la resuelve en cada caso", si bien propone que "al ser claramente restrictivo el uso de la tilde en el adverbio solo, lo más recomendable es respetar la norma general de no ponerlo" (2011: 556).

18 Hasta entonces todos los diccionarios de la Academia, de difusión mucho mayor que sus publicaciones ortográficas, tuvieron solo adjetivo y adverbio, sin acentuar en ambos casos, en una misma entrada, y a partir de 1925 se registran en artículos separados, ya con tilde en la forma adverbial.

19 Hay importantes diarios españoles en los que por línea editorial se ha impuesto la norma académica, pero de ella con frecuencia escapan algunos artículos, colaboraciones ocasionales y anuncios; también en América dista mucho de ser unánime la aplicación de las últimas reglas. Y la sustitución de $q$ por $c$ en el topónimo Catar tampoco hasta ahora ha desterrado la grafía Qatar, que no es raro ver en la prensa escrita y sobreimpreso en informativos televisivos. 
misma Real Academia Española recién fundada en su primer diccionario, de gran modernidad en tantos aspectos, mantuvo la ese alta, mucho antes denostada por Mateo Alemán y en la época de muy escaso uso, como raro era el empleo de una doble ss intervocálica, grafía ya ausente en capitales textos del siglo XV, acogida en este gran diccionario (assentar, assessor, aviesso, esse, osso...) con criterio etimológico o de origen del todo reñido con el de la pronunciación ${ }^{20}$. Y si, como arriba se cita, para la Academia en su Prontuario ortográfico de 1857 el uso "es árbitro de las lenguas", posteriormente en una de sus ediciones gramaticales reconocería que "los esfuerzos de nuestros gramáticos porque llegue a escribirse la lengua castellana tal como se habla, y las tiránicas leyes del uso, incontrastables las más veces, son causa de que unos vocablos se escriban conforme a la etimología, y otros no" (RAE 1931: 478).

Pero la Academia pausadamente, hasta 1763 no abandonaría la anacrónica ss intervocálica, intentaría modernizar y hacer más sencilla la ortografía, y este "espíritu de liberalidad, bien diferente del que suele animar tales cuerpos" Bello se lo reconoce (ASALE 2010a: 18). A renglón seguido el sabio chileno de adopción encomia "las reformas útiles" académicas y, sobre todo, "la docilidad del público en adoptarlas, tanto en la Península como fuera de ella"; pero su opinión tiene no poco de retórica, pues Bello bien sabía que el acatamiento de las reglas ortográficas distaba mucho de esa general docilidad; de hecho menudeaba la comisión de faltas, resultante de una mala enseñanza y de una ortografía que consideraba demasiado

20 No eran corrientes en el siglo XVIII textos en los que en posición intervocálica se pusiera

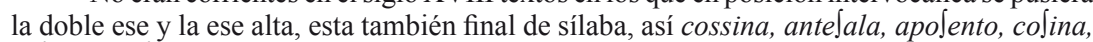
de $\int$ penza, e calera, que sin traba fonética alguna se encuentran en Plano de "lo que falta por fabricar en los altos y partes de los bajos del Palacio Real de la Ciudad de Guadalajara": Archivo General de Indias (AGI), MP, México 204, año 1756. Era en documentos jurídicos y administrativos de alto nivel donde estas grafías arcaicas habían hallado algún refugio, al parecer sobre todo en Ultramar. Así, en los Autos de oficio fulminados en el Tribunal de Guerra de Lima contra tres ingleses huídos de la cárcel, del año 1710, con continuo uso de ambas, o en el Traslado del expediente formado a petición del fiscal, sobre la llegada a las Filipinas del enemigo inglés, de 1742, con constante empleo de la -ss-: AGI, Lima 484; Filipinas 257 , N. 1. Pero la más rancia tradición ortográfica igualmente podía transmitirse a través de una enseñanza no reglada y anclada en viejos usos escriturarios, creo que también con más incidencia en América que en la Península, de lo cual es muestra la obra en verso Narración verdadera del funesto sucesso que en la más triste noche del más alegre día de Sr. Sn. Nicolás de Tolentino..., del mexicano Joseph Antonio de los Covos y Moxica, referida al trágico accidente acaecido en Iguala el diez de septiembre de 1744: Biblioteca Nacional de España, Ms. 12968-30. Este manuscrito descubre un frecuente y etimológicamente indiscriminado empleo de la -ss-: cassa, depusso, expulssos, inquisissión, etc. con grafías de los tipos vn, vna, vsurpo y honrras. 
erudita y de excesiva complejidad referencial en lo fonético. Por ello también juzga insuficientes las reformas hasta entonces introducidas en el modelo ortográfico, "este sistema de circunspección es tal vez inseparable de un cuerpo celoso de conservar su influjo sobre la opinión del público", y así, en coincidencia "con el plan progresivo de la Academia, autorizado ya por el consentimiento general", se siente asistido de razón y libertad para "aventurar algo más", a fin de preparar y acelerar "la época en que la escritura uniformada de España y de las naciones americanas presentará un grado de perfección desconocida hoy en el mundo" (22). Y ello siguiendo un método "más sencillo y racional" que el académico, desterrando las letras superfluas, fijando reglas "para que no haya letras unísonas", bajo la premisa de "adoptar por principio general el de la pronunciación, y acomodar a ella el uso común y constante sin cuidarse de los orígenes" (34). Intento de objetividad fonética, pues, y simplificación tanto teórica como de inventario grafémico, con trasfondo social y americanista.

Se buscaba, en efecto, una ortografía más sencilla que la existente, es decir la académica y la mantenida por la secular tradición escrituraria, en buena medida coincidentes, salvo por las variantes arcaicas que esta arrastraba y los arreglos normativos que desde su fundación la institución académica había ido introduciendo. Pero la cautela con que obraba la Academia resultaba excesivamente parsimoniosa para un reformador como Bello, que abomina de la incorrección en el lenguaje y en la escritura, y procuraba la efectividad pedagógica. Sarmiento incluso teñía de victimismo patriótico la comisión de faltas a que se veían abocados tantos americanos y achacaba al manejo de una ortografía que no correspondía a su pronunciación, otro argumento a favor de la independencia cultural y, más vagamente, de autonomía idiomática. En el fondo latía un sentimiento antiespañol y de reivindicación nacionalista que presentó diversas caras y grados en las elites criollas.

5.3. Sin embargo, no era solo cuestión achacable al empleo de una ortografía académica que no llegaba a todos los centros escolares del mundo hispánico, y mucho menos a tantísimos preceptores que individualmente ganaban su sustento con el menester de las primeras letras, sino al hecho de que la enseñanza de la escritura en muchos sitios se practicaba con variantes que la Academia española había desechado, pero que siglos atrás tuvieron cabida en los mejores textos castellanos ${ }^{21}$ y se habían mantenido en una transmisión de

21 El empleo de la $i$ como grafía de la conjunción copulativa y a final de palabra preconizado por Nebrija, pero con presencia textual muy anterior ( $i$ ' $y$ ' constante en el Auto de los Reyes 
la escritura muy alejada de la profesionalización actual, con gran dispersión en cuanto al seguimiento de cánones y por lo general más preocupada por el aspecto caligráfico que por el ortográfico. Es lo que se verifica en los manuscritos del negro oriental Jacinto Ventura de Molina, nacido en 1766 y protegido del brigadier español José de Molina, escolarizado siendo niño de modo semejante al que sirvió para que muchos americanos accedieran a las primeras letras. En su memoria quedó "el día que el maestro Dn. Mateo Cabral me puso en catón a leer de corrido", y se puede intuir la formación de dicho Cabral por este nuevo recuerdo suyo: "Aquel saserdote Dn. Josef Galeano ecsaminó al maestro Dn. Mateo Cabral. Mi señor le dio casa, mesas, sillas, bancos y le pidió por grasia que me educase y enseñase como a los demás niños" (Molina 2010: 103, 109). El mismo Jacinto enseñaría la escritura a otros, igual que el boliviano Vargas, quien, con el único bagaje de la primera formación en una escuela de Oruro, a sus dieciocho años en Oputaria un "don Fermín Morales, alcalde de aquel lugar, me llamó a su casa con destino de que le prestase mis servicios con la pluma y le enseñase a escribir a un hijo que tenía" (Vargas 1982: 20).

Este tipo de enseñanza de la escritura fue corriente en la inmensidad americana, con maestros de primeras letras y preceptores de toda la clase y condición, sin que a ella fueran del todo ajenos miembros de la elite criolla: Jacinto Ventura de Molina fue condiscípulo del P. Larrañaga, y el 25 de junio de 1810 escribía Javiera Carrera a su marido: "Mil cariños de Pío, el que ya está dando los nominativos de segunda; su memoria es feliz y no por esto deja de escribir con Martínez para perfeccionar la letra" (Vergara Muñoz 1987: 74-75). Está claro que en el caso de los Carrera, y sus autógrafos bien lo demuestran, la influencia de la ortografía más asentada en la lengua escrita culta, incluso la puramente académica, tenía que ser mayor que en los de individuos de nivel popular, como Vargas y Molina. Los manuscritos de este, caligráficamente correctos, registran con reiteración la $y$ inicial e interior de palabra (yjo, yndesente, naypes, etc.), también la $i$ final de vocablo, por copulativa y como grafía de /y/, la $r r$ alguna vez a comienzo de palabra (rrodillas) y constantemente después de $n$ (desenrrollos, Enrrique, ynrracional, onrra, onrroso, etc.), usos que de manera más o menos ocasional se hallan en textos de otros dominios americanos (Frago 2012: 79, 93). Y estas particularidades arcaizantes solo

Magos), se sigue como norma en Del origen i principio de la lengva castellana o romance que oi se v a en Elpaña (1606), de Aldrete; y la $r r$ inicial de palabra y después de $n$ se encuentra en códices del siglo XV como el burgalés Fernán González o el Libro del Caballero Zifar de la Bibliothéque National de France, entre otros. 
a una formación de raíces muy tradicionales y escasamente sujeta a reglas académicas podía deberse.

La coexistencia de variantes era, pues, inevitable, así como la comisión de faltas (en el empleo de la $h$, de $b$ y $v$, etc.), que una mala enseñanza no podía remediar; lo cual no significa que los textos americanos resultaran caóticos en su aspecto ortográfico, pues, aparte de que los niveles culturales por clases sociales y por regiones eran diversos, ni siquiera los individuos de escasa instrucción estaban ayunos del influjo de los cultos. Con insuficiente información se ha afirmado que en la Colonia no se usaban las tildes, lo cual no responde a la realidad, ni esta cuestión se puede abordar sin advertir qué ocurría al respecto en la manuscritura de la metrópoli, según en otra parte advierto (2012: 81-82). Vargas, el guerrillero altoperuano, puso algunas tildes, y con parquedad también las usó el negro Molina, quien confiesa: "siendo Su Señoría (el brigadier José de Molina) mui puntual en ortografía, a que jamás he sido yo aplicado..."; pero también presume de que "ningún niño en el Río grande, Santa Teresa, Montevideo y Buenos Aires en la escuela me abentajó en la doctrina, en las tablas y cuentas, en leer y conocimientos de los puntos, comas, 2 puntos, ynterrogaciones, acmiraciones, etc." (Molina 2010: 79, 106 ${ }^{22}$. Y desde luego al lado de una extendida desidia en el manejo de la ortografía afloraban deseos de corrección en esta faceta de la lengua escrita, que parecen apuntar en las últimas citas de Molina, y con impactante crudeza en el trágico relato hecho en prisión por José María Arrubla, "un caballero de los más distinguidos de Santafé", poco antes de morir fusilado por los realistas el 10 de septiembre de 1816: "No sé ortografía; arregla los períodos y adivina muchas líneas [borrada una o dos palabras] todo el día, qué quieres que haga en orden! No tuve educación para sufrir a palo seco una borrasca tan terrible" (Vanegas Useche 2011: 478-479). Y preciso interés por el buen uso ortográfico y su enseñanza escolar expresaba el mismo año de 1816 el mexicano Fernández de Lizardi en su literaria escena del cura que reprende al maestro ignorante:

si no sabe usar los caracteres ortográficos, no los pinte jamás, pues menos malo será que sus cartas y todo lo que escriba lo fíe a la discreción de los

22 Los editores ponen con tilde dos términos de este pasaje (abentajó, leér). Es muy posible que el catón con que el maestro Cabral puso a leer a Molina se hubiera imprimido en España, como lo fueron varias obras que este autor dice haber leído. 
lectores, sin gota de puntuación, que no que por hacer lo que no sabe, escriba injurias o blasfemias como la presente $(1846: 20)^{23}$.

5.4. Había un deficiente sistema escolar en la América colonial, y mucha despreocupación por la enseñanza de la ortografía - mutatis mutandis también en la metrópoli-, incluso en círculos de relevancia sociocultural, de manera que la comisión de lapsus no encontraba demasiadas cortapisas, con reacciones puristas sin embargo, y en tal situación el problema se agravaba ante la necesidad de mantener diferenciadas, de acuerdo con el uso establecido, las letras implicadas en los fenómenos del seseo y del yeísmo. Ese contraste entre la pronunciación americana y el canon ortográfico -que asimismo afectaría a andaluces y canarios- motivaría el artículo bogotano que se atreve a sugerir "el sonido puramente castellano" para remediarlo (cfr. 4.5.). Porque el prestigio de la pronunciación española persistiría en muchos americanos, y todavía en 1891 el dominicano César Nicolás Penson reprocha a Cuervo que se atenga a la Academia, "si en matería de lenguaje es Ud. más autoridad que ella, y como Ud., ciertos notables filólogos americanos singularmente", añadiendo:

Pues sepa Ud. que en la mayor parte de América la única autoridad es Bello, Baralt, Caro, Merchán, Isaza, Fidel Suárez, Ud. y otros, y luego los escritores españoles contemporáneos más acreditados para lo que es la buena dicción castellana (Romero 1992: II, 264-265).

Pero también era natural que se buscase adecuar la ortografía a la pronunciación americana, más aún teniendo en cuenta la situación de independencia política, por lo que en 1822 la Gazeta de Bogotá publicó la propuesta de que "para escribir como se pronuncia, y pronunciar como debe ser, se ha proyectado suprimir al alfabeto castellano cuatro letras, a saber $c$

23 José Joaquín Fernández de Lizardi es el autor de El Periquillo Sarmiento, que se publicó como anónimo en México el año 1816; aquí manejo la séptima edición, primera hecha en Chile, ejemplar perteneciente al Archivo Central Andrés Bello de la Universidad de Chile: con la autoría en seudónimo El Pensador Mejicano, ref. 80/1982/206. Fr. Manuel de Mercadillo en autógrafos de 1822 en que polemiza con este autor, "conocido por el pensador de Méjico" (como "Señor Pensador", irónicamente se le dirige), a pesar de su relevante nivel cultural y del buen estilo y corrección gramatical que sus textos descubren, comete algunas faltas en puntuación y tildado, desde luego más correcto de lo que podían suponer quienes con alguna gratuidad niegan esta práctica ortográfica en la Colonia. Pero, sobre todo, sus errores son numerosos en cacografías condicionadas por el seseo, y por el yeísmo en segundo lugar: Biblioteca Nacional de España, Ms. 21345.1-3. 
$q x z$, corruptoras de la buena pronunciación", aunque una voz discordante en el mismo periódico a continuación reclamó respeto a dichas letras, "naturales del abecedario colombiano y vecinas de Colombia", y contra el "injusto destierro" al que se las quería condenar (Guitarte 1983: 108), y el desaparecido americanista trae a colación una cita de la Gramática y ortografía de la lengua nacional (Buenos Aires, 1817) de Antonio J. Valdés, quien apunta al yeísmo como rasgo general de la pronunciación rioplatense, tomándolo por "provincialismo", pues aconseja su enmienda, y reconoce la distorsión ortográfica que el fenómeno fonético podía ocasionar:

Los preceptores deben tener particular esmero en que sus alumnos no confundan el uso de esta letra con el de la $y$, como ordinariamente se observa en la pronunciación y escritura (Guitarte 1983: 137-138) ${ }^{24}$.

La lenidad hacia los deslices ortográficos termina cuando la independencia política lleva aparejado un deseo de autonomía cultural respecto de España en miembros de las elites dirigentes, que los fustigan en aras de las nuevas tendencias educativas, en las que la corrección de la lengua hablada y escrita se adoptó como herramienta pedagógica esencial. En este ambiente de creciente normatividad, y de nacionalismo lingüístico en distintos grados de manifestación, era inevitable que se intentara la simplificación ortográfica con adaptación de los cánones existentes a la pronunciación americana ${ }^{25}$. Andrés Bello se ve condicionado por la consideración del seseo y del yeísmo como "provincialismos", opinión muy extendida entre los americanos, seguramente más en el aspecto ortográfico que en el fonético, lo cual coarta la sencillez de su reforma; también la prudencia de quien sabía que el terreno movedizo que pisaba le limitaba el derribo de letras del alfabeto.

La contradicción que Bello comete al mantener la $b$ y la $v$ no puede juzgarse anacrónicamente, pues la Academia desde su fundación venía arrastrando la confusión de letra y sonido en este caso, a mi parecer guiada

24 Es lamentable que este gran americanista sea ignorado por algunos filólogos "jóvenes", que tal vez por ignorancia culpable pierden así una inestimable referencia científica. De todos modos, parece ser práctica habitual hoy la cita sectaria o endogámica en grupos que quizá piensen que con ellos nació la auténtica filología, algo que en sus estudios no siempre demuestran.

25 Se ha visto, sin embargo, que las cosas no sucedieron ni lineal ni tajantemente en esta cuestión, pues la dicción española durante mucho tiempo mantuvo su prestigio entre no pocos americanos. Recuérdese lo dicho por Penson en 1891; y en 1910 el mexicano Manuel G. Revilla, después de indicar que en su país se habían perdido "los sonidos fuertes $c$ y $z, j$, y a las veces el de la $x$ y el suavísimo de la $l l$ ", advierte que "implícitamente se reconoce esta necesidad de la recta pronunciación..." (Guitarte 1983: 111). 
por el deseo de asegurar una difícil distinción ortográfica de dichas $b$ y $v^{26}$. Y si Bello se equivoca cuando atribuye referencia fónica a la $h$ muda en el vulgarismo consistente en confundir "la $g$ con la aspiración de la $h$, pronunciando guevo en lugar de huevo" (ASALE 2010a: 59), el error de la misma Academia podía venirle, pues en su Ortografía de 1820 trata de la "aspiración de la $h$ antes de la sílaba $u e$ ", y años después aún insistiría en el único caso en que $h$ tiene sonido, "el cual se confunde con el de la $g$ suave, es cuando precede al diptongo we, como en huerto, vihuela" (RAE 1857: 15).

\section{EPÍLOGO, CON MUDANZA ORTOGRÁFICA}

6.1. La verdad absoluta tiene difícil encaje en cuestión tan problemática como la que aquí se trata, pues son muchos los factores de toda índole que en ella concurren, afines a la consecución de la meta propuesta unas veces, y contradictorios otras. Contaba, por ejemplo, la escasa efectividad de las normas académicas en la escuela americana del siglo XVIII y primeras décadas del XIX, pero la regla tenía excepciones y casos hay de riguroso acatamiento, en la letra impresa particularmente, a dictámenes de la Academia española, alguno de los cuales sería luego revocado por la misma institución. Sin embargo, este aspecto de la historia de la ortografía no ha sido convenientemente estudiado.

26 En el Discurso proemial ortográfico del primer diccionario académico se dice que "el uso de la $b$ y de la $v$ causa mucha confusión, nacida de que los españoles, como no hacemos distinción en la pronunciación de estas dos letras, igualmente nos hemos valido ya de la $b$ ya de la $v$ sin el menor reparo", y para allanar su empleo se propone el criterio etimológico o del origen, y, ante la duda, "siempre se debe usar la $b . .$, , porque es más connatural a nuestra manera de hablar la pronunciación de la $b$ que de la $v$ " (RAE 1726-1739/1969: LXXII); y no diferencia en rigor la Academia por el sonido en las correspondientes entradas dos letras que desde hacía siglos se referían a uno solo. En su primera Ortografia (1741) afirma que "la $b$ confunde nuestra lengua con la $v$ consonante, porque en nuestra infancia no nos enseñaron a articular con distinta pronunciación la $v$ de la $b$ ", y habla de "especulativo precepto" el de hacer aprender pronunciaciones distintas para estas dos letras, algo tan artificioso que "nos es imposible practicar la obediencia". Pero en la de 1820 la Academia insiste en aconsejar la práctica escolar distinguidora, probablemente en busca de la corrección ortográfica, y resulta al menos ambigua al decir que "el confundir el sonido de la $b$ y de la $v$ " es "culpa de la mala costumbre adquirida en los vicios y resabio de la mala educación doméstica y de las primeras escuelas, que naturaleza de sus voces". 
En América antes de su independencia ya se había empezado a sentir el problema de la corrección idiomática, con la referencia a las diferencias culturales y sociales que en su consideración inevitablemente se planteaban. La ortografía cobraba especial interés porque en su uso se manifestaban distintos grados de habilidad, o de respeto a costumbres escriturarias establecidas, pero asimismo se apreciaba la dificultad que el americano experimentaba a la hora de manejar sin confusión distinciones ortográficas $(s-c, z, l l-y, b-v)$ sin correspondencia en su habla. Y el problema en cuestión queda apuntado ya el año 1808 en la Gazeta bogotana arriba citada (cfr. 4.5.).

$\mathrm{El}$ autor de este texto pensaba en la pronunciación del "castellano puro" como freno del desorden ortográfico, algo que de todos modos habría sido ilusorio remedio, pero la próxima emancipación americana vendría acompañada de un cambio en las mentalidades, sin cortapisas ya para creer y publicar que "la letra $z$ es eminentemente española" (Guitarte 1983: 109), en confusión evidente de letra y sonido, y se recordará que el año 1822 se defendió su proscripción (cfr. 5.4.), antes, pues, de que Bello diera a la luz su propuesta reformista.

Es cierto que la $z$ mantuvo defensores en América, así como "la buena dicción castellana", y que no faltaban quienes en actos solemnes o en la lectura se esforzaban por practicarla, como el general Rosas según el testimonio de su sobrino Mansilla, que lo oyó "pronunciando la ce, la $z$, la ve y la be, todas las letras, con la afectación de un purista". También se conoce el caso del asimismo argentino José Antonio Miralla, de cuyo paso por Bogotá en 1824-1825 un colombiano que lo trató recordaba con admiración: "A nadie he oído pronunciar la lengua castellana con tanta pureza y corrección. Nunca confundía la $b$ con la $v$, ni la $z$ con la $s$ " (Guitarte 1983: 109, 118-119).

Sin embargo, entre cruces de afectos y desafectos culturales, entre polémicas y contradicciones tanto conceptuales como metódicas, se había abierto el camino a la simplificación ortográfica y a su adecuación a la realidad americana, con ponderada cautela por parte de Bello y con ímpetu reformista en Sarmiento, aunque sin llegar a las últimas consecuencias de su planteamiento, de quien Guitarte sospecha que como maestro de escuela también había enseñado la pronunciación de la $z$ (1983: 118). En medio de oposiciones corrieron aires favorables a la reforma de Sarmiento, que, atemperada como solución chilena, respondía a impulsos surgidos en muchas partes de América, y desde Chile, según el citado americanista, "se extendió por varios países del Pacífico, Venezuela y Nicaragua, con un grado de penetración que aún no conocemos exactamente" (1983: 179). 
6.2. Pero a pesar de los entusiasmos iniciales, esta ortografía americana iría retrocediendo ante la panhispánica, que acabaría siendo reconocida en el mismo Chile, no solo porque había sido la de todos y continuaba siéndolo para muchos americanos, sino porque un cambio ortográfico de tal envergadura requiere la remoción de obstáculos que a veces resultan insalvables. La ortografía casera también tuvo seguidores en Colombia, donde encuentro un caso paradigmático de conversión ortográfica, concretamente en el bogotano Luis María Lleras, amigo y corresponsal de Rufino José Cuervo. Efectivamente, el gran filólogo usaba la ortografía común, mientras Lleras empleaba $i$ como conjunción y final de palabra (hai, $h o y, s o i)$ y $j$ en exclusividad (Ánjel, jeneral, jente, jerente). No obstante, en la misiva que escribe a Cuervo el 6 de marzo de 1883, ya con mezcla de los dos modelos, después de poner estoy y una $y$ conjuntiva se cree obligado a dar esta explicación: "Le advierto, para que no estrañe la ortografía, que estoy empezando a usar las íes griegas, i que me pasa lo que al que estudia dos idiomas a un tiempo" (Hernández de Alba 1969: 54) 27. Tras algunos tanteos y dudas, pronto su mudanza sería completa.

\section{REFERENCIAS BIBLIOGRÁFICAS}

Asociación de Academias de la Lengua Española (ASAlE). 2010a. Gramática de la libertad. Andrés Bello y la unidad lingüistica panhispánica. Valparaíso: Aguilar Chilena de Ediciones.

2010b. Diccionario de americanismos. Lima: Santillana Ediciones Generales.

Cid, Gabriel (ed.). 2009. El Mercurio Chileno. XVI, julio de 1829. Santiago de Chile: Dirección de Bibliotecas, Archivos y Museos.

CONTRERAS, Lidia. 1991. Sarmiento y la polémica ortográfica en Chile. Actas del VIII Congreso de ALFAL. México-Tucumán: UNAM-UNT, 184-187.

Deas, Malcolm. 1993. Miguel Antonio Caro y amigos: gramática y poder en Colombia. Del poder y la gramática, y otros ensayos sobre historia, politica y literatura colombianas. Bogotá: Tercer Mundo de Editores, 25-60.

Ferreccio Podestá, Mario. 1979. Las fuentes de la Filología chilena. El catálogo anónimo de 1843. Atenea 440, 39-59.

27 En esta carta las grafías americanas predominan sobre las comunes, y la variación se advierte en la misma despedida: "Saludo a Anjel con un abrazo. Su affmo. amigo y compadre". En las tres posteriores continúa la dualidad ortográfica, con creciente peso de los usos panhispánicos, que ya se han impuesto en la siguiente cuarta misiva, del 12 de julio de 1883, donde la $y$ ha desplazado a la $i$, y Lleras ya escribe Ángel el nombre del hermano de Rufino José Cuervo. 
Frago, Juan Antonio. 1999. Historia del español de América. Textos y contextos. Madrid: Gredos.

2010a. El español de América en la Independencia. Santiago de Chile: Taurus. 2010b. Sobre el español de Chile: del período colonial al independiente. Boletín de Filología 45/1, 103-126.

2011. Cuestiones de norma lingüística en décimas de la insurgencia colombiana. Onomázein 24/2, 327-348.

2012. Lecciones lingüísticas en versos mexicanos de la Independencia. Boletín de la Real Academia Española 92/305, 71-96.

Guitarte, Guillermo L. 1983. Siete estudios sobre el español de América. México: Universidad Nacional Autónoma de México.

Hernández de Alba, Gulllermo (ed.). 1969. Epistolario de Rufino José Cuervo con Luis María Lleras y otros amigos y familiares. Bogotá: Instituto Caro y Cuervo.

Herrera Dávila, José y Antonio Alvear. 1845. Lecciones de gramática castellana, 5 a edición. Santiago de Chile.

Molina, Jacinto Ventura de. 2010. Los caminos de la escritura negra en el Río de la Plata. Edición de William Acree y Alex Borucki. Madrid: Iberoamericana.

NoÉ, JuAN NiCOLÁs. 1837. Epitome de gramática castellana para uso de las escuelas primarias. Valparaíso: Imprenta de la Bandera.

Oroz, Rodolfo. 1966. La lengua castellana en Chile. Santiago: Universidad de Chile.

Real Academia Española (RAE). 1726-1739/1969. Diccionario de autoridades. Madrid: Gredos.

1857 . Prontuario de ortografía de la lengua castellana para el uso de las escuelas públicas. Madrid: Imprenta Nacional.

— 1931. Gramática de la lengua española. Madrid: Espasa Calpe.

1999. Ortografía de la lengua española. Madrid: Espasa Calpe.

Real Academia Española (RAE) y Asociación de Academias de la Lengua española (ASALE). 2005. Diccionario panhispánico de dudas. Madrid: Santillana Ediciones Generales. Espasa Libros.

2011. Nueva gramática de la lengua española. Fonética y fonología. Barcelona:

2012. Ortografía básica de la lengua española. Barcelona: Espasa Libros.

Romero, Mario Germán (ed.). 1992. Epistolario de Rufino José Cuervo con corresponsales hispanoamericanos. Bogotá: Instituto Caro y Cuervo.

Rosenblat, Ángel. 1951. Las ideas ortográficas de Bello. En Andrés Bello, Estudios gramaticales. Obras completas V. Caracas: Ministerio de Educación, IX-CXXXVIII.

1971. Fetichismo de la letra. Nuestra lengua en ambos mundos. Barcelona: Biblioteca General Salvat, 41-81.

Santamaría, Francisco J. 1978. Diccionario de mejicanismos. 3ª edición. México: Editorial Porrúa.

Sarmiento, Domingo Faustino. 1997. Viajes por Europa, África i América, 1845-1847. Javier Fernández (coord.), $2^{\mathrm{a}}$ edición. Madrid: ALLCA XX.

2002. Obras selectas. Edición de Diana Sorensen. Madrid: Espasa Calpe.

Seco, Manuel. 2011. Nuevo diccionario de dudas y dificultades de la lengua española. Barcelona: Espasa Libros.

VANegas Useche, Isidro (comp.). 2011. Dos vidas, una revolución. Epistolario de José Gregorio y Agustín Gutiérrez Moreno (1808-1816). Bogotá: Editorial Universidad del Rosario.

VARGaS, José SANtos. 1982. Diario de un comandante de la Independencia americana, 18141825. Edición de Gunnar Mendoza. México: Siglo Veintiuno. 
Verdevoye, Paul. 1988. La cuestión de la ortografía en Domingo Facundo Sarmiento. Educar y escribir opinando. Buenos Aires: Edición Plus Ultra.

Vergara Muñoz, Sergio (ed.). 1987. Cartas de mujeres en Chile, 1630-1885. Santiago de Chile: Editorial Andrés Bello.

Vergara Quiroz, Sergio (ed.). 1999. Manuel Montt y Domingo F. Sarmiento. Epistolario, 1833-1888. Santiago de Chile: Dirección de Bibliotecas, Archivos y Museos. 